\title{
Bank-specific, Industry-specific and Macroeconomic Determinants of Banks Profitability: Empirical Evidence from Tanzania
}

\author{
Saganga M. Kapaya \\ Department of Accounting and Finance, the Open University of Tanzania \\ Dar Es Salaam, Tanzania
}

Tel: 255-022-2667450Ｅ-mail: saganga.mussa@out.ac.tz

\begin{abstract}
Gwahula Raphael
Directorate of Research and Postgraduate Studies, the Open University of Tanzania

Dar Es Salaam, Tanzania
\end{abstract}

Tel: 255-022-2667450_E-mail: gwahula.raphael@out.ac.tz

Received: August 5, 2016 Accepted: August 30, 2016 Published: September 22, 2016

doi:10.5296/ifb.v3i2.9847 URL: http://dx.doi.org/10.5296/ifb.v3i2.9847

\begin{abstract}
The study analyzed effects of bank-specific, industry-specific and macroeconomic determinants on banks profitability. It used a maximum of 350 firm-years, from 52 banks from 1998 to 2010 in Tanzania. It did proxy profitability using return on asset (ROA), return on equity (ROE) and net interest margin (NIM). The static fixed effects regression model indicated that; credit facilities (CFA), capital adequacy (TEA), credit risk (CFR), diversification ratio (DIV), bank risk (BAR) and financial market development (MCAd) were significantly influencing ROA. The dynamic fixed effects regression model indicated that lagged ROA, TEA, loan losses provisions (PLT) and BAR, were significantly influencing ROA.
\end{abstract}

Keywords: ROA, NIM, Banks, Profitability, Tanzania, Panel data 


\section{Introduction}

A strong banking sector is argued (Almazari, 2014) to be capable of confronting negative shocks in the financial system. Factors both internal and external affect the performance of banks. Internal factors are management decisions on financial statements, size of the bank, capital, gearing levels, risk levels and expenses management affect profitability directly. External factors are economic in nature; these are inflation, interest rates, market concentration, and industry size and ownership status (Almazari, 2014). The objective of this paper is to assess profit variability in the banking sector as influenced by both internal and external factors in Tanzania. Previous studies (Almazari, 2014) concentrated on internal factors only, some other studies (Gul et al., 2011; Jaber, 2014) included both internal and external factor. The question is whether it is possible to gain more from both groups of factors that if we consider them in a combination.

\section{Theoretical and Empirical Review}

\subsection{Theoretical Review}

There are generally three sets of factors that are known to affect bank profitability. Firm-specific factors which are inherent to the firm, industry-specific factors which are extrinsic to the firm but innate to the type of industry and macroeconomic factors that sweep the economy in which banks are operating.

\subsubsection{Bank Profitability}

Return on asset (ROA), captures the aspect of performance of a bank in terms of its profitability, it is the ratio of net income to total assets. It is a ratio that is directly affected by internal factors of a bank that are financial conditions of a bank, but as well as external factors to a bank such as economic conditions and government policies (Almazari, 2014; Saeed, 2014; Jaber, 2014; Gul et al., 2011) Return on Equity (ROE), measures the rate of return of ownership interest of common stock owners. It measures the efficiency in generating profit from every unit of equity ownership. It shows how best a firm uses investment fund in generating profit growth (Saeed, 2014; Gul et al., 2011). Return on capital employed (ROCE), is arguably similar to ROA but ROCE takes into account the sources of financing. It is the ratio of non-markup income to capital employed (Gul et al., 2011). Net interest margin (NIM), is a measure of the difference between interest income and interest expense relative to the value of the assets. It is as a rule articulated as a percentage of what the bank earns on loans and other assets in a time period minus the interest expensed on borrowed funds divided by the average value of the assets on which it earned income in that time period (Gul et al., 2011).

\subsubsection{Firm-specific Factors}

Liquidity risk (LQR), captures the risk of loss to a bank resulting from its inability to meet its needs for cash or from its inadequate liquidity levels normally covered by fund obtained at an excess cost (Almazari, 2014; Jaber, 2014). Liquidity is an imperative internal condition for a bank to be able to provide credits. Banks are normally required to maintain a certain 
minimum level of liquidity to be able to meets its functions (Saeed, 2014). Higher liquidity should promote higher profitability. Loan (Credit facility) or Net credit facilities to total assets (CFA), captures the core function of a bank, that of surplus spending units excesses being directed to deficit spending units shortages, that is lending and borrowing function. From these activities the bank earns net interest margins. The larger the loan the higher the net interest margin and consequently the higher the bank profit. It is expected that the higher the CFA the higher the ROA (Gul et al., 2011; Almazari, 2014; Saeed, 2014).

Non-interest investments: Total investment to total assets (TIA), captures bank investment other than leading activities. These are non-interest incomes such as commissions, services charges, guarantee fees, other fees, profits from sales of investment securities and forex profits. The increasing level of non-interest incomes is an indication of diversification. It is expected that the higher the TIA the higher the ROA (Sufian \& Noor, 2012). Capital (Equity): Total equity to total assets (TEA), this ratio captures the idea of capital adequacy which represent the strength and soundness of the bank. It indicates the ability of a bank to absorb general shocks, the higher the TEA the higher the ROA (Gul et al., 2011; Almazari, 2014). Net credit facilities to total deposit ratio (CFR), is the bank's financial loss risk due to borrowers' failure to perform their obligations. For high risk banks, the relationship between CFR and ROA is expected to be negative (Almazari, 2014; Jaber \& Al-khawaldeh, 2014).

Cost income ratio (CIR), this is a proxy for operational efficiency. It captures the idea of bank improvements in communication, information and financial technologies. An advance in technologies has a positive impact on banking operations efficiency. Thus we expect a negative relationship between CIR and ROA (Almazari, 2014; Jaber, 2014). The size of the bank (SZE), large banks are theoretically capable of economies of scale which consequently lower average costs. Thus, bank size (SZE) has a positive impact on ROA (Almazari, 2014). Larger banks are arguably better placed than smaller banks in harnessing economies of scale (Gul et al., 2011). Deposit ratio: Total deposits to total assets (DAR), captures liquidity and liability indications in the bank. Deposits are the main sources of bank funding (Gul et al., 2011), and hence has an important impact on profitability of the bank. The more deposits a bank receives the more its ability to offer loans is enhanced, thus there would be a positive relationship between deposits and profitability (Saeed, 2014).

Provisions for loan losses to total loans (PLT), captures the concept of capital risk. The provisions for loan losses-to-total loans ratio measures credit risk. This is the non-performing loans to total loans. We expect that the higher the provisions the lower the profitability (Athanasoglou et al., 2006). Diversification ratio (DIV) is the ratio of non-interest income to total income. The impacts of diversification on banks ROA, when macroeconomic and structural factors are controlled indicates that diversification benefits do accrue up to a certain degrees, that is $30 \%$ of the diversification ratio. The results indicate that revenue diversification goes together with increase in the ROA (Gambacorta et al., 2014) Interest earning businesses are normally considered as riskier than fee-based businesses, which would call for higher return rewards (Flamini et al., 2009). Another factor is bank risk (BAR), we measure BAR using standard deviation of returns on equity. Central banks normally impose limitations on gearing for their banks. Equity happens to be the primary financing vehicle for 
banks and second to none. The variability on equity would ultimately determine the profitability of banks in any setting. Hoffmann (2011) argues that, regulators and supervisory entities that set minimums for equity capital, and establish other types of regulations in order to deter excessive risk taking, can affect the bank's capital structure decisions, and hence its earnings. Following the method of Hoffmann, we measure risk as the standard deviation of return on equity. Risk is expected to be positively or negatively related to profitability.

\subsubsection{Industry-specific Factors}

Industry-specific factors are factors that are outside the control of management. They represent phenomena that are not under the control of the bank. But, management is capable of anticipating changes in these phenomena and positions their banks to take advantages out of them. These factors are financial market development and market capitalization (MCAd). There are both complementary effect and substitution effect between direct financing and indirect financing. Thus the connection between the banking sector and financial markets are indecisive. Development of financial markets weakens loans demands by creating a competitive relationship between them. In the meantime, there is a certain complementary association between banking sector and financial markets because of their mutual promotion roles in the development process (Pan \& Pan, 2014). Under perfect market conditions, Gul et al. (2011) argue that debt and equity act as perfect substitutes. Thus, equity financing has a negative effect to profitability compared to debt financing. Consequently, whether the substitution effect or the complementary effect prevails depends on direction of the effect.

Financial structure/ banking sector size (FSR): researches in banking examine whether financial structure, which is defined as the comparative significance of banks, plays a position in influencing banking performance. Normally, a high banks total assets-to-GDP ratio shows that financial development plays a vital role in the economy. The size of the banking is intended to measure the significance of bank financing in the economy. This comparative significance might mirror a higher demand for banking services, which in turn, draws more prospective competitors to enter the market. When the market is more competitive, banks have to take diverse strategic moves in order to maintain their profitability. FSR indicate the substitutability and complementarities between equity and bank financing. It is expected to influence positively or negative bank ROA.

Market concentration/competitiveness/market power (MCA_twoB): it is normally captured by the ratio of the two largest banks assets to total banking industry assets. It can as well be measured by the Herfindalh-Hirschman index (HHI) which measures industry concentration or competitiveness in the market or industry. The HHI is calculated as the sum of the squared market shares in total assets of the individual banks. In order to maintain market competitiveness of commercial banks profitability should be enhanced (Pan \& Pan, 2014). It can also be measured as the impact of managerial inefficiency (proxied by the log of overheads costs). Operating costs are found to be high in Sub-Saharan Africa, which indicates a lack of competitive pressure. High operating costs are expected to erode profits unless they are shifted to depositors and lenders. It can also be captured by the coefficient of the squared size variable. This coefficient controls for non-linearities in the size-profitability connection, 
due to potential diseconomies of scale as banks increase in size. If such a coefficient turns out to be negative but statistically non-significant, this would supply evidence that banks benefit from enough market power to be able to pass costs on to costumers (Flamini et al., 2009; Athanasoglou et al., 2006).

\subsubsection{Macroeconomic Factors}

Inflation (INF) captures the idea of level of price in the economy. It affects companies pricing behaviour, for instance, expectation of high inflation in the future triggers manager to adjust their prices by moving them upward, without expecting a drop in the demand of the product (Gul et al., 2011). Inflation has an effect on fiscal policy and monetary policy. Prudent fiscal policy and tight monetary policy slow down economic growth, as a result reduce profits. In addition, the impact of inflation depends on whether it has been anticipated or not anticipated, that is, if it is anticipated the effects on ROA is positive, if not anticipated the effect would be negative on ROA (Pan \& Pan, 2014).

Monetary policy (MPO): quantitative monetary policies affect the profitability of commercial banks through the control of money supply. Monetary policy will enhance the money supply, which directly enhances the existing funds of commercial banks, by this it means increasing the interest income of the bank. Also the increase in demand for bonds increases its price. There is a reverse association between bond prices and interest rates. Higher bond prices lead to lower interest rates, which fuels consumption and enhance investment, enlarge the size of commercial bank credit; in that way increasing the profitability of commercial banks. Lending rates relates to earnings of commercial banks: the increase of interest rates decrease the number of loans, and loan interest increases, in that way leading to variations in profitability of commercial bank (Pan \& Pan, 2014).

\subsection{Hypothetical Arguments}

Under the assumption of perfect markets hypothesis, that is absence of taxes, no frictions and no barriers to entry, distribution of perfect information is asymmetrical and there is absence of deposit insurance. Under such conditions both book and market values of equity are identical. Increasing equity by substituting debt reduces the risk of both securities and lower the market required rate of return as long as investors are risk averse and cannot diversify the bank risk. In this scenario we expect a negative relationship between capital and profitability. But, when market imperfections do arise, the relationship may be reversed into a direct one (Hoffmann, 2011).

There are two possible accounts for a positive association between the bank's profits and the capital ratio. One, the expected bankruptcy costs hypothesis, which implies that the greater the exogenous variables rising its expected bankruptcy costs, the higher the optimal capital ratio for a bank is going to be. Two, the signaling hypothesis provide explanations for the positive association between capital ratio and profits. The symmetric information assumption is relaxed, giving managers a chance to have confidential information about the potential stream of cash flows. As a result, managers may be willing to signal this information through capital decisions. As a result, a signaling equilibrium may possibly exist, in which banks that 
anticipate to have better future performance have higher capital. In theory, a bank's ability to take in unanticipated losses establishes its risk level. An extremely high capital ratio may signify that a bank is operating unadventurously and is not taking advantage of potentially profitable investment opportunities and consequently may lead to lower profits (Hoffmann, 2011; Obamuyi, 2013).

In line with the capital ratio and profitability relationships, two more arguments are advanced. One, from the efficiency-risk hypothesis, more efficient firms are inclined to prefer comparatively low equity ratios, because anticipated returns from greater profit efficiency substitute equity capital to some extent, in a sense of shielding the firms against financial distress, bankruptcy, or liquidation. Two, from the franchise-value hypothesis, more efficient firms have a tendency to prefer comparatively high equity ratios to shield future income derived from high profit efficiency. Consequently, in line with the previous arguments, a non-monotonic linear relationship between profitability and capital ratio is expected (Hoffmann, 2011).

A different branch of study on the determinants of profitability focuses to the market-power (non-structural approach) and efficient-structure hypotheses (structural approach). The market-power hypothesis, or the structure-conduct-performance hypothesis, argues that there is a positive relationship between banking concentration and performance, for the reason that increased market-power produces monopolistic profits. The collusion hypothesis also argues for a positive relationship between banking concentration and profitability. This hypothesis argues, "a small number of banks may possibly collude, either surreptitiously or openly". This cartel may lead to more expensive loans and lower interest rates on deposits for individual investors. But when the number of banks is high it becomes difficult to collude. The efficient structure hypothesis posits that banks/firms with superior management or production technologies have lower cost and thus higher profits, these firms normally have high market share and resulting high level of concentration, implied is the idea that highly concentrated markets lower the cost of collusion, thus collusion causes positive effects to profits (Hoffmann, 2011; Athanasoglou et al., 2006).

In a nutshell, these hypotheses explore, correspondingly, whether a highly concentrated market leads to collusive tendencies among the larger banks, resulting in superior market profitability, and whether it is the efficiency of larger banks that causes their superior profitability. Therefore, banks in more concentrated markets will reap higher profits (for collusive or monopolistic reasons) compared to banks operating in less concentrated markets, irrespective of their efficiency. Thus, the market power hypothesis considers bank profitability as a function of external market power while efficient structure hypothesis consider bank profitability as a function of internal efficiencies (Hoffmann, 2011; Athanasoglou et al., 2006; Obamuyi, 2013).

\subsection{Empirical Evidences}

Almazari (2014) studied banking sector using a panel of 23 major Saudi Arabian and Jordanian Banks, from 161 observations and found intriguing results; positive relationships between profitability and soundness of a bank (total equity and total asset ratio), negative 
relationship between profitability and size and operational efficiency (cost income ratio) for both samples. While liquidity, net credit facilities to total assets, total investment to total assets ratio, and net credit facilities to total deposits have reversed relationships to profitability in the two countries.

Gul et al. (2011) using a panel of 15 top banks in Pakistan for 5 years (2005-2009) found that bank size, loan, deposits, GDP and inflation have a positive significant impact on ROA, while capital and market capitalization have negative relationship with ROA. Jaber (2014) studied a sample with 66 observations for years 2007-2012 using both internal and external factors to determine profitability. He finds that internal varibles; capital adequacy, cost to income ratio, liquidity ratio and bank size are all negatively related to profitability. $\mathrm{He}$ also finds that external variables; stock market capitalization and inflation with the exception of GDP are positively related to profitability. He further aggregated the factors, and find that aggregate internal factors are negatively related to profitability and aggregate external factors are positively related to profitability.

Pan \& Pan (2014) studied 10 listed Chinese banks between 1998 and 2012, and find that economic development (GDP) and monetary policies (M1, lending interest rates) have positive relationship with bank profitability while stock market development has a negative relationship with profitability. Saeed (2014) studied 73 UK based commercial banks for the years 2006-2012 and found that bank size, capital ratio, deposits, loan, liquidity, and interest rate are positively related to ROA and ROE while GDP and inflation rate are negatively related to ROA and ROE.

\subsection{Research Hypotheses}

\section{H1: there is a relationship between banks' internal/bank specific factors and banks profitability.}

H1a: Liquidity risk does not affect bank's profitability

H1b: A net credit facility to total assets does not affect bank's profitability

H1c: Total non-interest investment to total assets does not affect bank's profitability

H1d: Total equity to total assets does not affect bank's profitability

H1e: A net credit facilities to total deposit ratio does not affect bank's profitability

H1f: Cost income ratio does not affect bank's profitability

H1g: Size of the bank does not affect bank's profitability

H1h: Deposits to total asset ratio does not affect bank's profitability

H1i: Non-performing loans to total loans ratio does not affect bank's profitability

H1j: Diversification ratio does not affect banks' profitability

H1k: Bank's risk does not affect bank's profitability 


\section{Al Macrothink}

H2: there is a relationship between banks' external factors (financial structure factors) and banks profitability.

H2a: Financial market development does not affect bank's profitability

H2b: Financial structure/banking sector size does not affect bank's profitability

H2c: Market concentration/competitiveness does not affect bank's profitability

H3: there is a relationship between banks' external factors (macroeconomic factors) and banks profitability.

H3a: Inflation does not affect bank's profitability

H3b: Monetary policy does not affect bank's profitability

\section{Research Methodology}

The study followed a quantitative approach. The sample was made up of a total of 42 banks from Tanzania, for years 1998 to 2010, making a total of 350 firm years. The data for bank specific variables was sourced from Bank Scope database, the data for financial structure and macroeconomic variables were sourced from Dar es Salaam stock exchange, World Bank database and IMF's International Financial Statistics.

The study employed an unbalanced panel data analysis. Panel data methodology has the following advantages; first, it has the benefit of giving extra informative data due to both cross sectional information, which captures entity specific variability, and the time series information, which captures dynamic adjustment. Second, it permits to study the effects of macroeconomic variables on profitability after controlling for entity specific characteristics, with a reduction of collinearity among variables, added degrees of freedom and superior efficiency. Thirdly, it overcomes the unobservable, constant and heterogeneous characteristics of each bank in the sample (Baltagi, 2001; Hoffmann, 2011).

Variables that were included in the analysis were; return on asset (ROA), return on equity (ROE), return on capital employed (ROCE) and net interest margin (NIM) as dependent variables. While, liquidity risk (LQR), net credit facilities to total assets (CFA), total investment to total assets (TIA), total equity to total assets (TEA), net credit facilities to total deposit ratio (CFR), cost income ratio (CIR) and the size of the bank (SZE), market concentration/competitiveness (MCO), inflation (INF), monetary policy (MPO) and financial market development (MCA) as independent variables.

The static regression model:

$$
Y_{i, t}=\alpha_{i}+\sum_{j} \beta_{j} X_{i, t}^{j}+\sum_{m} \beta_{m} X_{t}^{m}+\sum_{n} \beta_{n} X_{t}^{n}+\mu_{i, t}
$$

Where $Y_{i, t}$ refers to ROA or ROE or NIM of bank $i$ for period $t ; \alpha_{i}$ is the unknown intercept for each entity (n-entity specific intercepts); $X_{i, t}^{j}, X_{t}^{m}$ and $X_{t}^{n}$ represent vectors of 
bank individual-time specific determinants and industry-structure time-specific determinants and macroeconomic time-specific determinants, respectively and $u_{i t}$ is the error term.

Table 1. Variable measurements and their respective proxies

\begin{tabular}{|c|c|c|c|c|}
\hline & Variables & Proxies & Symbols & Researchers \\
\hline & \multicolumn{4}{|l|}{ Dependent variable: } \\
\hline $1 \mathrm{a}$ & Return on assets ratio & Net income / Total Assets & ROA & $\begin{array}{l}\text { Almazari (2014), Gul et al. (2011), Pan } \\
\& \text { Pan (2014), Saeed (2014), Hoffmann } \\
\text { (2011), Athanasoglou, et al. (2006) }\end{array}$ \\
\hline $1 \mathrm{~b}$ & Return on equity & Net income / Total Equity & ROE & $\begin{array}{l}\text { Gul et al. (2011), Saeed (2014), } \\
\text { Athanasoglou et al. (2006) }\end{array}$ \\
\hline $1 \mathrm{c}$ & $\begin{array}{l}\text { Return on capital } \\
\text { employed }\end{array}$ & $\begin{array}{l}\text { Non-markup income / Capital } \\
\text { Employed }\end{array}$ & ROCE & Gul et al. (2011) \\
\hline \multirow[t]{3}{*}{$1 d$} & Net interest margin & $\begin{array}{l}\text { Net interest income / Total } \\
\text { Assets }\end{array}$ & NIM & Gul et al. (2011) \\
\hline & \multicolumn{4}{|l|}{ Independent variables: } \\
\hline & \multicolumn{4}{|c|}{ Internal factors: Bank specific variables } \\
\hline 1 & Liquidity risk & $\begin{array}{l}\text { Cash and Cash Equivalent / } \\
\text { Total Assets }\end{array}$ & LQR & $\begin{array}{l}\text { Almazari (2014), Gul et al. (2011), Jaber } \\
\& \text { Al-khawaldeh (2014), Saeed (2014) }\end{array}$ \\
\hline 2 & $\begin{array}{l}\text { Bank Loan (Credit } \\
\text { facilities) }\end{array}$ & $\begin{array}{l}\text { Net Credit Facilities / Total } \\
\text { Assets }\end{array}$ & CFA & $\begin{array}{l}\text { Almazari (2014), Gul et al. (2011), } \\
\text { Saeed (2014), Athanasoglou et al. (2006) }\end{array}$ \\
\hline 3 & $\begin{array}{l}\text { Non-interest } \\
\text { Investment }\end{array}$ & $\begin{array}{l}\text { Total non-interest investment / } \\
\text { Total assets }\end{array}$ & TIA & $\begin{array}{l}\text { Sufiani \& Noor (2012), } \\
\text { Almazari (2014), }\end{array}$ \\
\hline 4 & Capital (equity) & Total Equity / Total assets & TEA & $\begin{array}{l}\text { Almazari (2014), Gul et al. (2011), } \\
\text { Hoffmann (2011), Obamuyi (2013) }\end{array}$ \\
\hline 5 & $\begin{array}{l}\text { Credit risk: Loan to } \\
\text { deposit ratio }\end{array}$ & $\begin{array}{l}\text { Net Credit Facilities / Total } \\
\text { Deposits }\end{array}$ & CFR & $\begin{array}{l}\text { Flamini et al. (2009) } \\
\text { Almazari (2014), Gul et al. (2011), } \\
\text { Jaber, (2014) }\end{array}$ \\
\hline 6 & Cost income ratio & $\begin{array}{l}\text { Total operating Expenses/ Total } \\
\text { operating Income }\end{array}$ & CIR & $\begin{array}{l}\text { Almazari (2014), Jaber (2014), Obamuyi } \\
\text { (2013) }\end{array}$ \\
\hline 7 & Bank size & $\begin{array}{l}\text { Natural logarithm of Total } \\
\text { Assets }\end{array}$ & SZE & $\begin{array}{l}\text { Almazari (2014), Gul et al. (2011), Jaber } \\
\text { (2014), Obamuyi (2013) }\end{array}$ \\
\hline \multirow[t]{4}{*}{8} & Deposit ratio & Total deposits / Total Assets & DAR & Gul et al. (2011), Saeed (2014) \\
\hline & Variables & Proxies & Symbols & Researchers \\
\hline & \multicolumn{4}{|l|}{ Independent variables: } \\
\hline & \multicolumn{4}{|c|}{ Internal factors: Bank specific variables } \\
\hline 9 & Loan losses & $\begin{array}{l}\text { Provision for loan losses/ Total } \\
\text { loans }\end{array}$ & PLT & Athanasoglou et al. (2006) \\
\hline 10 & Diversification ratio & $\begin{array}{l}\text { Non-interest income/ Total } \\
\text { income. }\end{array}$ & DIV & Gambacorta (2014), \\
\hline \multirow[t]{2}{*}{11} & Bank risk & $\begin{array}{l}\text { Standard deviation of returns on } \\
\text { equity }(\sigma \mathrm{ROE})\end{array}$ & BAR & $\begin{array}{l}\text { Hoffmann (2011), } \\
\text { Stierward (2009) }\end{array}$ \\
\hline & \multicolumn{4}{|c|}{ External factors: Financial structure variables } \\
\hline 1 & $\begin{array}{l}\text { Financial market } \\
\text { development }\end{array}$ & $\begin{array}{l}\text { Ln (Market capitalization of } \\
\text { stocks) }\end{array}$ & MCAd & Gul et al. (2011), Pan \& Pan (2014) \\
\hline 2 & $\begin{array}{l}\text { Financial structure } \\
\text { (Size of the banking } \\
\text { sector) }\end{array}$ & Banks total assets /GDP & FSR & Ramadan et al. (2011) \\
\hline \multirow[t]{2}{*}{3} & $\begin{array}{l}\text { Market (industry) } \\
\text { concentration / } \\
\text { competitiveness/ } \\
\text { Market power }\end{array}$ & $\begin{array}{l}\text { The ratio of total of } 2 \text { banks } \\
\text { assets over total industry assets. }\end{array}$ & MCA_twoB & $\begin{array}{l}\text { Pan \& Pan (2014), Flamini et al. } \\
\text { (2009), Athanasoglou et al. (2006), } \\
\text { Wong et al. (2007). }\end{array}$ \\
\hline & \multicolumn{4}{|c|}{ Macroeconomic variables } \\
\hline 1 & Inflation & growth of consumer price index & INF & Gul et al. (2011), Pan \& Pan (2014) \\
\hline 2 & Monetary policy & Money supply growth & MPO_one & Pan \& Pan (2014) \\
\hline
\end{tabular}


To take into account the tendency of profits to be persistent over time, owing to market structure imperfections or high sensitivity to auto-correlated macroeconomic factors, a dynamic specification of the model is adopted, following Flamini et al. (2009) and Athanasoglou et al. (2006) approach, with a lagged dependent variable among the regressors. This yields the following model specification:

The dynamic regression model:

$$
Y_{i, t}=\alpha_{i}+\varphi Y_{i, t-1}+\sum_{j} \beta_{j} X_{i, t}^{j}+\sum_{m} \beta_{m} X_{t}^{m}+\sum_{n} \beta_{n} X_{t}^{n}+\mu_{i, t}
$$

Where $Y_{i, t-1}$ is the one period lagged profitability and $\varphi$ measures the speed of mean reversion. A value of phi $(\varphi)$ between 0 and 1 indicates that profits are persistent, but they will finally go back to the equilibrium point. Particularly, values close to 0 indicate a high speed of adjustment and imply comparatively competitive market structure, while a value closer to 1 implies slower mean decline, and, as a result, less competitive markets.

\section{Findings and Discussion}

\subsection{General Sample Characteristics and Treatments}

The total number of observation in the study was 350 firm-years. Table 2 provides the summary statistics of our data, for the banks in Tanzania between 1998 and 2010. Table 3 provides a matrix of correlations of the variables under study. The correlations are generally lower indicating lack of multi-co-linearity problem in our data; this is further confirmed by the overall VIF which was 3.18. The upper limit considered tolerable is 5.

Table 2. Summary statistics

\begin{tabular}{|l|l|l|l|l|l|l|l|l|l|l|}
\hline & Count & Mean & Std. & Min. & Max. & Skewness & Kurtosis & p25 & p50 & p75 \\
\hline ROA & 350 & 0.01 & 0.04 & -0.43 & 0.10 & -4.36 & 35.53 & 0.01 & 0.02 & 0.03 \\
\hline ROE & 350 & 0.13 & 0.36 & -3.16 & 1.94 & -3.43 & 33.10 & 0.03 & 0.16 & 0.29 \\
\hline ROCE & 350 & 0.01 & 0.04 & -0.43 & 0.10 & -4.36 & 35.53 & 0.01 & 0.02 & 0.03 \\
\hline NIM & 350 & 0.06 & 0.03 & -0.02 & 0.20 & 1.50 & 5.85 & 0.04 & 0.05 & 0.07 \\
\hline 1ROA & 350 & 0.01 & 0.04 & -0.25 & 0.10 & -2.46 & 11.80 & 0.00 & 0.02 & 0.03 \\
\hline 1ROE & 350 & 0.13 & 0.34 & -3.16 & 2.06 & -2.31 & 32.42 & 0.01 & 0.15 & 0.28 \\
\hline 1ROCE & 350 & 0.01 & 0.04 & -0.25 & 0.10 & -2.46 & 11.82 & 0.00 & 0.02 & 0.03 \\
\hline 1NIM & 350 & 0.06 & 0.03 & -0.02 & 0.20 & 1.33 & 5.75 & 0.04 & 0.05 & 0.07 \\
\hline LQR & 350 & 0.40 & 0.18 & 0.04 & 0.84 & 0.25 & 2.47 & 0.27 & 0.38 & 0.52 \\
\hline CFA & 350 & 0.41 & 0.16 & 0.00 & 0.89 & -0.24 & 2.77 & 0.31 & 0.43 & 0.53 \\
\hline TIA & 350 & 0.00 & 0.01 & 0.00 & 0.07 & 5.53 & 37.62 & 0.00 & 0.00 & 0.00 \\
\hline TEA & 350 & 0.14 & 0.15 & 0.00 & 0.93 & 2.19 & 8.98 & 0.03 & 0.09 & 0.17 \\
\hline CFR & 349 & 0.55 & 0.24 & 0.00 & 2.35 & 1.32 & 11.75 & 0.41 & 0.54 & 0.68 \\
\hline SZE & 350 & 24.4 & 1.84 & 19.37 & 28.4 & -0.13 & 2.42 & 23.1 & 24.4 & 25.9 \\
\hline DAR & 350 & 0.78 & 0.13 & 0.00 & 1.18 & -1.87 & 9.17 & 0.75 & 0.81 & 0.86 \\
\hline PLT & 349 & 0.00 & 0.03 & 0.00 & 0.49 & 18.41 & 342.14 & 0.00 & 0.00 & 0.00 \\
\hline DIV & 350 & 0.30 & 0.13 & -0.01 & 0.84 & 0.60 & 3.74 & 0.21 & 0.29 & 0.37 \\
\hline BAR & 350 & 0.05 & 0.03 & 0.03 & 0.11 & 1.32 & 3.78 & 0.03 & 0.04 & 0.07 \\
\hline CIR & 350 & 2.37 & 14.8 & -95.8 & 85.8 & -1.78 & 21.69 & 1.08 & 2.47 & 5.17 \\
\hline MCAd & 274 & 20.1 & 0.61 & 19.01 & 20.9 & -0.32 & 2.14 & 19.8 & 20.2 & 20.3 \\
\hline FSR & 350 & 0.02 & 0.03 & 0.00 & 0.21 & 3.90 & 19.25 & 0.00 & 0.00 & 0.01 \\
\hline MCA_twoB & 350 & 0.37 & 0.08 & 0.31 & 0.57 & 1.76 & 4.61 & 0.33 & 0.34 & 0.35 \\
\hline INF & 350 & 7.72 & 3.13 & 4.74 & 16.0 & 1.13 & 3.19 & 5.30 & 6.20 & 10.2 \\
\hline MPO_one & 350 & 20.7 & 6.76 & 10.78 & 34.7 & 0.76 & 2.86 & 14.8 & 19.8 & 25.4 \\
\hline$N$ & 350 & & & & & & & & & \\
\hline
\end{tabular}


The static and dynamic regression models were analyzed. The static models have on average indicated that the variations on profitability explainable by the factors under study were ROA $(\mathrm{r} 2=0.30)$, ROE $(\mathrm{r} 2=0.16)$, ROCE $(\mathrm{r} 2=0.30)$ and NIM ( $2=0.32)$; while the 1ROA ( $\mathrm{r} 2=$ $0.34), \operatorname{ROE}(\mathrm{r} 2=0.27)$, IROCE $(\mathrm{r} 2=0.34)$ and INIM $(\mathrm{r} 2=0.41)$. The values for average industry $\operatorname{ROA}(0.01)$, ROE (0.13), and NIM (0.06) indicates that banks in Tanzania are operating at lower levels of profitability, coupled with high liquidity LQR (0.40) and lower risk TEA (0.14).

The values for ROA and ROCE are perfectly correlated indicating that they are measuring the same thing: profitability, while ROE and NIM are less correlated indicating they are measuring different aspects of profitability. In choosing between FE and RE we tested whether individual effects are random, Ho: both fixed effects (FE) and random effects (RE) are consistent, Ha: RE effects is not consistent or FE is consistent. The Hausman specification test indicated the following for ROA, ROE and NIM static models (Table 4): ROA- accepts Ha ( $p=0.0000$, chi $2=100.05)$, FE consistent. ROE- accepts Ha ( $p=0.0000$, chi2=370.48), FE consistent. NIM- accepts Ha ( $p=0.0069$, chi2=30.30), FE consistent. While for the dynamic models 1 ROA- accepts $\mathrm{Ha}(\mathrm{p}=0.0000$, chi2 $=51.42)$, FE consistent. IROE- accepts Ha $(p=0.0000$, chi $2=333.71)$, FE consistent. 1 NIM- accepts Ha $(p=0.0000$, chi2 = 73.21), FE consistent. All the models fit were significant at $1 \%$ Thus, our interpretations are based on FE models. We tested for time effects in data, tests indicated lack of time effects.

\subsection{Firm-specific Factors}

The whole sample analysis indicated that, all lagged values for ROA and NIM (IROA and INIM respectively) have positive effects on profitability of banks significant at 0.01 ; with the exception of $1 \mathrm{ROE}$ this was negative and significant at 0.01 . Thus prior year's profitability is essential in promoting next year's profitability. The 0.29 for IROA indicating that profits are persistent, but they will finally go back to the equilibrium point. This value which is less than average indicates an average high speed of adjustments and a comparatively competitive market structure. Consistent to the findings of Moussa (2012) and Ongore (2013) who found a positive but insignificant effect of LQR on profitability; our results were not only positive but significant; except for 1 ROE (Table 4). The LQR of 0.40 (Table 2) is averagely high, which is also confirmed by Qin \& Pastory (2012), high liquidity which means that banks are less exposed to liquidity risk and are likely going to earn high profits. Davydenko (2010) found a negative relationship for ROA for all banks excluding the largest 10 and positive relationship for 10 largest banks.

Consistent to Ahmad et al. (2012) and Jaber \& Al-khawaldeh (2014) findings, we found TEA to be consistently negative but not significant relationship, except for ROA (static model) and ROA (dynamic model) (Table 4). This indicates that as liquidity risk decreases the banks earns more profits, if not so then TEA serves as an unreliable or poor proxy for liquidity risk (Goddard et al., 2004). 
Table 3. Correlation matrix

\begin{tabular}{|c|c|c|c|c|c|c|c|c|c|c|c|c|}
\hline & ROA & ROE & ROCE & NIM & IROA & IROE & IROCE & INIM & LQR & CFA & TIA & TEA \\
\hline ROA & 1 & & & & & & & & & & & \\
\hline ROE & $0.28^{* * \bullet}$ & 1 & & & & & & & & & & \\
\hline ROCE & $1.00^{* * *}$ & $0.28^{* * *}$ & 1 & & & & & & & & & \\
\hline NIM & $0.23^{* * *}$ & 0.01 & $0.23^{* * *}$ & 1 & & & & & & & & \\
\hline IROA & $0.63^{* * *}$ & $0.22^{* * *}$ & $0.63^{* * *}$ & $0.18^{* * *}$ & 1 & & & & & & & \\
\hline IROE & $0.35^{* * *}$ & $0.32^{* * *}$ & $0.35^{* * *}$ & 0.06 & $0.45^{* * *}$ & 1 & & & & & & \\
\hline IROCE & $0.62^{* * *}$ & $0.23^{* * * *}$ & $0.62^{* * *}$ & $0.18^{* * *}$ & $1.00^{* * *}$ & $0.45^{* * *}$ & 1 & & & & & \\
\hline INIM & $0.14^{* *}$ & 0.04 & $0.14^{* *}$ & $0.72^{* * *}$ & $0.34^{* * *}$ & 0.03 & $0.34^{* * *}$ & 1 & & & & \\
\hline LQR & $0.16^{* *}$ & $0.12^{\circ}$ & $0.16^{* *}$ & $-0.14^{* *}$ & $0.19^{* * *}$ & 0.09 & $0.19^{* * *}$ & $-0.11^{\circ}$ & 1 & & & \\
\hline CFA & 0.01 & -0.04 & 0.01 & $0.32^{\circ * *}$ & 0.00 & -0.05 & 0.00 & $0.24^{\ldots *}$ & $-0.76^{\circ * *}$ & 1 & & \\
\hline TIA & $-0.11^{*}$ & -0.08 & $-0.11^{*}$ & $-0.14^{* *}$ & $-0.11^{\circ}$ & -0.07 & $-0.11^{*}$ & $-0.14^{* *}$ & $-0.11^{*}$ & -0.01 & 1 & \\
\hline TEA & $-0.53^{* \cdots}$ & $-0.23^{* * *}$ & $-0.53^{* * *}$ & -0.03 & $-0.51^{* * *}$ & $-0.34^{* * *}$ & $-0.51^{\cdots *}$ & -0.07 & $-0.18^{* * *}$ & -0.01 & $0.16^{* *}$ & 1 \\
\hline CFR & -0.02 & -0.07 & -0.02 & $0.28^{* * *}$ & -0.04 & -0.08 & -0.04 & $0.23^{* * *}$ & $-0.71^{* \cdots *}$ & $0.88^{* * *}$ & 0.08 & $0.21^{* * *}$ \\
\hline SZE & $0.27^{* * *}$ & $0.25^{* * *}$ & $0.27^{* * *}$ & $-0.39^{* * *}$ & $0.30^{* * *}$ & $0.36^{* * *}$ & $0.30^{* * *}$ & $-0.30^{* * *}$ & $0.11^{\circ}$ & $-0.16^{* *}$ & 0.02 & $-0.42^{* * *}$ \\
\hline DAR & 0.08 & 0.06 & 0.08 & -0.03 & 0.09 & -0.04 & 0.09 & -0.04 & $0.11^{\circ}$ & 0.06 & $-0.16^{* *}$ & $-0.59^{* * *}$ \\
\hline PLT & $-0.31^{* * *}$ & $0.15^{* *}$ & $-0.31^{* * *}$ & $-0.12^{*}$ & $-0.18^{* * *}$ & -0.10 & $-0.17^{* *}$ & -0.03 & -0.05 & -0.05 & -0.01 & $0.29^{* * *}$ \\
\hline DIV & -0.02 & 0.00 & -0.02 & $-0.42^{* * *}$ & -0.03 & -0.02 & -0.03 & $-0.31^{* * *}$ & $0.29^{* * *}$ & $-0.38^{* * *}$ & $0.24^{* * *}$ & $-0.12^{\circ}$ \\
\hline BAR & $-0.22^{* * *}$ & -0.08 & $-0.22^{* * *}$ & -0.06 & $-0.10^{\circ}$ & $-0.13^{*}$ & $-0.10^{\circ}$ & 0.01 & -0.02 & -0.07 & -0.00 & 0.05 \\
\hline CIR & $0.10^{\circ}$ & 0.08 & $0.10^{\circ}$ & 0.01 & $0.17^{* * *}$ & $0.10^{\circ}$ & $0.17^{* * *}$ & $0.13^{\circ}$ & 0.02 & -0.08 & -0.01 & $-0.21^{* * *}$ \\
\hline MCAd & -0.04 & -0.02 & -0.04 & 0.03 & $-0.13^{\circ}$ & -0.10 & $-0.13^{\circ}$ & -0.00 & -0.05 & 0.06 & 0.01 & 0.08 \\
\hline FSR & $0.17^{* *}$ & $0.23^{* *}$ & $0.17^{* *}$ & -0.08 & $0.21^{* * *}$ & $0.31^{* * *}$ & $0.21^{* * *}$ & -0.05 & 0.09 & -0.07 & -0.03 & $-0.29^{* * *}$ \\
\hline MCA_twoB & 0.01 & 0.00 & 0.01 & -0.01 & 0.08 & 0.08 & 0.08 & 0.02 & 0.08 & -0.07 & -0.02 & -0.04 \\
\hline INF & $-0.10^{\circ}$ & -0.08 & $-0.10^{\circ}$ & -0.06 & -0.02 & -0.00 & -0.02 & 0.01 & 0.04 & -0.03 & -0.02 & 0.04 \\
\hline MPO_one & 0.04 & 0.09 & 0.04 & -0.03 & -0.02 & -0.04 & -0.02 & -0.08 & 0.00 & -0.05 & 0.00 & 0.00 \\
\hline
\end{tabular}

Table 3. Correlation matrix (Continue)

\begin{tabular}{|c|c|c|c|c|c|c|c|c|c|c|c|c|}
\hline & CFR & SZE & DAR & PLT & DIV & BAR & CIR & MCAd & FSR & MCA twoB & INF & MPO_one \\
\hline CFR & 1 & & & & & & & & & & & \\
\hline SZE & $-0.19^{* * *}$ & 1 & & & & & & & & & & \\
\hline DAR & $-0.33^{* * *}$ & $0.14^{* *}$ & 1 & & & & & & & & & \\
\hline PLT & -0.06 & -0.08 & 0.04 & 1 & & & & & & & & \\
\hline DIV & $-0.39^{* * *}$ & $0.20^{* * *}$ & $0.13^{\circ}$ & -0.01 & 1 & & & & & & & \\
\hline BAR & -0.07 & 0.06 & 0.03 & 0.04 & -0.00 & 1 & & & & & & \\
\hline CIR & -0.07 & 0.09 & 0.01 & -0.01 & -0.02 & 0.01 & 1 & & & & & \\
\hline MCAd & 0.01 & -0.09 & 0.06 & -0.08 & -0.01 & -0.07 & -0.05 & 1 & & & & \\
\hline FSR & $-0.12^{*}$ & $0.59^{* * *}$ & $0.11^{\circ}$ & -0.02 & 0.08 & 0.05 & 0.03 & $-0.29^{* * *}$ & 1 & & & \\
\hline MCA_twoB & -0.02 & 0.07 & -0.06 & 0.01 & -0.01 & -0.02 & 0.02 & $-0.72^{* * *}$ & $0.32^{* * *}$ & 1 & & \\
\hline $\mathrm{INF}^{-}$ & -0.03 & 0.00 & 0.00 & -0.03 & -0.00 & -0.02 & 0.01 & $-0.14^{\circ}$ & $0.16^{* *}$ & $0.52^{* * * *}$ & 1 & \\
\hline MPO_one & -0.05 & -0.01 & -0.00 & -0.04 & 0.03 & 0.05 & -0.01 & $0.28^{* * *}$ & $-0.16^{* *}$ & $-0.43^{* * *}$ & $-0.50^{* *}$ & 1 \\
\hline$N$ & 350 & & & & & & & & & & & \\
\hline
\end{tabular}

Also he argues that, the relationship is expected to be either positive or negative, as capital asset ratio (TEA) and liquidity ratio (LQR) are normally used to proxy for risk. He further argues that, conflict of interest between managers and shareholders may make the relationship between profitability and other variables difficult to disentangle, because while shareholders want to maximize profit managers might be willing to sacrifice profits to reduce risk by undertaking more secure activities. In theory an excessive TEA means that the banks are operating over cautiously and avoiding potentially profitable investments, the opposite 
would as well be true. Thus, arguably Tanzanian banks are taking on potentially profitable investments that have less risk because TEA is 0.14 .

CFA was negatively related to ROA and NIM, while positively related to ROE and NIM for static models and positive relationship for the dynamic models. Similarly, Davydenko (2010) found a positive and significant value for Ukranian banks, while Ramadan et al. (2011) found a positive and insignificant value for Jordanian banks. This indicates the relative size of credit facility is influencing profitability. TIA was negative but not significant, except the positive values to NIM. Our findings indicated that banks have high credit risk, average of 0.55 (Table 2), CFR was positive and significant at 0.01 for ROA. It indicates that bank's financial loss risk due to borrowers' failure to perform their obligation increases profits. Other studies that found a positive relationship is for instance Flamini et al. (2009) who did a similar study conducted for banks in Sub-Saharan Africa found a positive relationship.

Findings for TIA were not significant; it helps to proxy for non-interest bearing activities that most banks have embarked on in Tanzania. It captures the idea of diversification of banks activities from traditional bank functions. The both static and dynamic models indicate negative relationships. This was not consistent to our expectations and other researchers' postulation, such as Sufian \& Noor (2012) who found positive and significant relationships. DIV captures the same idea but it splits incomes into non-interest incomes from interest incomes. The findings indicate an average of 0.30 of total income as coming from non-interest incomes. Gambacorta et al. (2014), postulate that diversification benefits normally accrue up to $30 \%$, beyond which it is not beneficial. The negative and significant relationship (Table 4) indicates that Tanzanian banks are no more benefiting from diversification.

SZE was found to be positive in the static model except for NIM, and negative in dynamic model (Table 4). When the SZE variable was squared to take care of non-linearity of the variable, it indicated a negative and significant at 0.01 relationships to ROA. These results are consistent to those of Athanasoglou et al. (2006) and Flamini et al. (2009). This provides evidence for the economies of scale theory (Athanasoglou et al., 2006). It is argued that firm size has a positive impact on profitability if larger firms benefit from economies of scope; exploit scale economies or access capital at lower costs than smaller firms. Few cost savings can be achieved by increasing the size of a banking firm, especially as markets develop. The effect of a growing bank's size on profitability may be positive up to a certain limit. Beyond this point the effect of size could be negative due to bureaucratic and other reasons. Hence, the size-profitability relationship may be expected to be non-linear (Athanasoglou et al., 2006). The size-squared coefficient controls for non-linearities in the size-profitability relationship, owing to possible diseconomies of scale as banks become too big. If such a coefficient turns out to be negative but statistically non-significant, this would provide evidence that banks enjoy enough market power to be able to pass costs on to customers (Flamini et al., 2009). The size-squared variable (not in tables) was negative and not significant, indicating that banks do not enjoy enough market power and are not able to pass costs on to customers. In Table 2 , DAR is shown to be at 0.78 , indicating that banks have a large amount of deposits which are available for loans. The static regression results indicate 
that it is positively related to ROA and NIM. It was negatively related to profitability in dynamic regressions. The finding is consistent to Gul et al. (2011).

As in Wong et al. (2007) provision for loan losses to total loans PLT, is included in the estimation to capture differences in the quality of banks' loan portfolios. The average in our analysis is nearly zero. The relationship is negative for ROA and NIM in both static as well as dynamic models, this result is consistent to that of Wong et al. (2007), who found not only negative relationship but also significant for ROA and NIM and Athanasoglou et al. (2006) who found a negative and significant relationship to ROA. They argue that a higher PLT of banks indicates a loan portfolio of poorer credit quality, which may lead to lower profits due to higher operating costs relating to credit risk and loan loss management. It may also trigger banks to shift to other assets with lower risks, resulting in lower interest rate spread. However, a higher net interest margin, NIM could reflect riskier lending practices associated with substantial loan loss provisions (Ongore, 2013).

In our case the lower PLT average ratio that is close to 0 with a maximum of 0.49 and NIM minimum (-0.02), maximum (0.20) and mean (0.00) (Table 2$)$ may indicate that the quality of loans is higher. The negative relationship indicates that provision for loan losses are responsible for reducing profitability of banks. A 1\% increase in loan losses provision results into an $11 \%$ decrease in profitability (ROA). Bank risk (BAR), as measured by the standard deviations of ROE indicated a negative relationship to ROA and NIM. Bank risk contributes to a reduction in profitability. The mean for risk was 0.05 indicating a lower bank risk. Similarly, Stierward (2009) found a negative but significant relationship between bank risk and ROA. He used variance of stock market return to proxy for risk, he found that the larger the variation in stock market returns the higher the individual risk. On the other hand, Hoffmann (2011) using standard deviations of ROE found a positive relationship between BAR and ROE.

\subsection{Industry-specific Factors}

The findings for MCAd indicate a small positive magnitude of effect on profitability. The effects to ROA and NIM are positive and significant. All that indicates that rather than the substitutionary effects, the complementary effects is persistent in Tanzanian banks.

Table 4. Static and dynamic fixed effects regression models

\begin{tabular}{|l|l|l|l|l|l|l|}
\hline & $(1)$ & $(2)$ & $(3)$ & $(4)$ & $(5)$ & $(6)$ \\
\hline & feROA & feROE & feNIM & felROA & felROE & felNIM \\
\hline IROA & & & & $0.2909^{* * *}$ & & \\
\hline IROE & & & & & $-0.0006^{* * *}$ & \\
\hline INIM & & & & & & $0.2652^{* * *}$ \\
\hline LQR & 0.0100 & -0.0514 & -0.0232 & 0.0311 & $0.7473^{* *}$ & 0.0024 \\
\hline CFA & $-0.1065^{*}$ & 0.6519 & -0.0050 & 0.0455 & $1.1735^{*}$ & 0.0442 \\
\hline TIA & -0.6788 & -0.3199 & 0.0709 & -0.3703 & -2.7149 & 0.1252 \\
\hline TEA & $-0.1003^{* * *}$ & -0.3614 & 0.0247 & $-0.0540^{*}$ & -0.2390 & 0.0322 \\
\hline
\end{tabular}




\begin{tabular}{|l|l|l|l|l|l|l|}
\hline CFR & $0.0928^{* *}$ & -0.5100 & 0.0246 & 0.0027 & -0.4038 & -0.0019 \\
\hline SZE & 0.0045 & $0.0947^{* *}$ & -0.0020 & -0.0016 & $0.1126^{* *}$ & -0.0026 \\
\hline DAR & 0.0095 & -0.5753 & 0.0212 & -0.0253 & $-0.9539^{* *}$ & -0.0008 \\
\hline PLT & -0.1108 & $3.3703^{* * *}$ & -0.0898 & $-0.3482^{* * *}$ & $2.3974^{* *}$ & $-0.1370^{* *}$ \\
\hline DIV & $-0.0510^{*}$ & 0.3495 & $-0.1043^{* * *}$ & -0.0044 & 0.3858 & $-0.0743^{* * *}$ \\
\hline BAR & $-0.2612^{* *}$ & -1.3528 & 0.0070 & $-0.1279^{*}$ & -1.4205 & -0.0265 \\
\hline CIR & 0.0000 & -0.0001 & -0.0000 & 0.0000 & 0.0002 & -0.0001 \\
\hline MCAd & $0.0156^{* *}$ & 0.0526 & $0.0073^{*}$ & 0.0051 & -0.0125 & 0.0023 \\
\hline FSR & 0.0482 & -1.5682 & 0.0175 & 0.0368 & -1.3117 & -0.0165 \\
\hline MCA_twoB & 0.0897 & 0.4106 & $0.0583^{*}$ & 0.0146 & 0.0886 & 0.0367 \\
\hline INF & -0.0021 & 0.0035 & $-0.0019^{* *}$ & 0.0001 & 0.0115 & $-0.0015^{*}$ \\
\hline MPO_one & -0.0003 & 0.0032 & -0.0002 & 0.0001 & $0.0064^{*}$ & -0.0002 \\
\hline$N$ & 316 & 314 & 316 & 276 & 273 & 276 \\
\hline r2 & 0.3021 & 0.1652 & 0.3260 & 0.3432 & 0.2735 & 0.4081 \\
\hline r2_a & 0.1172 & -0.0579 & 0.1473 & 0.1599 & 0.0723 & 0.2430 \\
\hline rmse & 0.0328 & 0.3050 & 0.0189 & 0.0221 & 0.2632 & 0.0158 \\
\hline mss & 0.1158 & 4.5463 & 0.0430 & 0.0548 & 5.5570 & 0.0371 \\
\hline rss & 0.2675 & 22.9809 & 0.0890 & 0.1048 & 14.7581 & 0.0537 \\
\hline F & 6.7380 & 3.0540 & 7.5259 & 6.6085 & 4.7178 & 8.7208 \\
\hline
\end{tabular}

Note. ${ }^{*} p<0.05,{ }^{* *} p<0.01,{ }^{* * *} p<0.001$.

That is, equity financing complements debt financing in improving profitability, as Pan and Pan (2014) puts it, there is a certain complementary association between banking sector and financial markets because of their mutual promotion roles in the development process. Other studies (Gul et al., 2011) have supported a substitionaty effect with a negative coefficient to ROA. The financial structure ratio (FSR), indicated a positive relationship to ROA, indicating that as the share of banking sector in the country GDP increases overall banks profitability increase. The lower FSR $(0.02$, that is $2 \%)$ indicates that the banking sector financial development plays a very small role in the GDP of the country. This low significance mirrors the low demand for banking services which in turn may scares away competitors to enter the market.

The ratio of the largest two banks, MCA_twoB was 0.37 indicating a monopolistic tendency in the market, as such may limit the development of other smaller banks. The results indicated a positive coefficient relationship to ROA, ROE and NIM for the dynamic models. As in the study of Flamini et al. (2009) we do not obtain conclusive results as to whether market power influences overall bank profitability (ROA) because the results were not significant, except NIM whose result was significant. Sufian (2012) using the ratio of the largest three banks, produced a mean of 0.36 , finds a positive and significant coefficient to ROA, supporting the structure-conduct hypothesis, that states bank in highly concentrated markets tend to collude and earn monopolistic profits, we tried to use three, four, five and six largest banks the results were not significant as well, only when we used the 
Herfindalh-Hirschman index did our coefficient turned to be negative but not significant. The mixed results and lack of significance between the outcomes remind us of the weaknesses in the proxies, as noted by Athanasoglou et al. (2009).

\subsection{Macroeconomic Factors}

Inflation INF, as one of the factors that affects the whole economy indicated a negative impact on ROA and NIM. Only the coefficient for NIM was significant. The mean for inflation in our study was high at $7.72 \%$. Theoretically, inflation reduces credit expansion by contributing to higher net interest margins (Flamini et al., 2009). They further argue that the extent to inflation effects on bank profitability depends on whether future movements in inflation are fully anticipated, which, in turn, depends on the ability of banks to accurately forecast future movements in the relevant control variables. An inflation rate that is fully anticipated raises profits as banks can appropriately adjust interest rates in order to increase revenues. Thus, the negative effect of INL in our results could point to the inability of banks to correctly forecast and anticipate inflation in the economy.

Athanasoglou (2009) argue that the question is how mature an economy is so that future inflation can be accurately forecast and thus banks can accordingly manage their operating costs. As such, the relationship between the inflation rate and profitability is unclear and depends on whether or not inflation is anticipated. An inflation rate fully anticipated by the bank's management implies that banks can correctly regulate interest rates in order to increase their revenues quicker than their costs and thus obtain higher profits. On the contrary, unanticipated inflation could lead to inappropriate adjustment of interest rates and consequently to the possibility that costs could increase more rapidly than revenues. Other researchers who have found the same negative effect to ROA Gul et al. (2011) argue that if banks expect general inflation to be higher in the future, they may believe that they can increase their prices without suffering a drop in demand for their output. Monetary policy proxied by money supply growth, MPO_one was negatively related to ROA, ROE and NIM. Theoretically, monetary policy will enhance the money supply, which directly enhances the existing funds of commercial banks, by this means increasing the interest income of bank.

Table 5. Hypotheses validation

\begin{tabular}{|c|c|c|c|c|c|c|c|}
\hline \multirow[t]{3}{*}{ Hypotheses } & \multirow[t]{3}{*}{ Expected signs on ROA } & \multicolumn{6}{|c|}{ Findings: } \\
\hline & & \multicolumn{3}{|c|}{ Static models } & \multicolumn{3}{|c|}{ Dynamic models } \\
\hline & & ROA & ROE & NIM & ROA & ROE & NIM \\
\hline Lagged ROA & + & & & & $+* * *$ & & \\
\hline Lagged ROE & + & & & & & $-* * *$ & \\
\hline Lagged NIM & + & & & & & & $+* * *$ \\
\hline H1a: LQR & + & $+!$ & $-!$ & $-!$ & $+!$ & $+* *$ & $+!$ \\
\hline H1b: CFA & + & $-*$ & $+!$ & $-!$ & $+!$ & $+*$ & $+!$ \\
\hline H1c: TIA & + & $-!$ & $-!$ & $+!$ & $-!$ & $-!$ & $+!$ \\
\hline H1d: TEA & + & $-* * *$ & $-!$ & $+!$ & $-*$ & $-!$ & + \\
\hline
\end{tabular}




\begin{tabular}{|l|l|l|l|l|l|l|l|}
\hline H1e: CFR & - & $+* *$ & $-!$ & $+!$ & $+!$ & $-!$ & $-!$ \\
\hline H1f: CIR & + & $+!$ & $-!$ & $-!$ & $+!$ & $-!$ & $-!$ \\
\hline H1g: SZE & + & $+!$ & $+* *$ & $-!$ & $-!$ & $+* *$ & $-!$ \\
\hline H1h: DAR & + & $+!$ & $-!$ & $+!$ & $-!$ & $-* *$ & $-!$ \\
\hline H1i: PLT & - & $-!$ & $+* * *$ & $-!$ & $-* * *$ & $+* *$ & $-* *$ \\
\hline H1j: DIV & $+/-$ & $-*$ & $+!$ & $-* * *$ & $-!$ & $+!$ & $-* * *$ \\
\hline H1k: BAR & $+/-$ & $-* *$ & $-!$ & $+!$ & $-*$ & $-!$ & $-!$ \\
\hline H2a: MCAd & $+/-$ & $+* *$ & $+!$ & $+*$ & $+!$ & $-!$ & $+!$ \\
\hline H2b: FSR & $+/-$ & $+!$ & $-!$ & $+!$ & $+!$ & $-!$ & $-!$ \\
\hline H2c: MCA_twoB & + & $+!$ & $-!$ & $+*$ & $+!$ & $+!$ & $+!$ \\
\hline H3a: INF & $+/-$ & $-!$ & $+!$ & $-* *$ & $+!$ & $+!$ & $-*$ \\
\hline H3b: MPO_one & $+/-$ & $-!$ & $+!$ & $-!$ & $+!$ & $+*$ & $-!$ \\
\hline
\end{tabular}

Note. ${ }^{*} p<0.05,{ }^{* *} p<0.01,{ }^{* * *} p<0.001$, ! Not significant, + positive, - negative.

Thus, the increase in the money supply will enhance the profitability of commercial banks. On the other hand, when the central bank shrinks the money supply, the size of credit will be reduced. Commercial banks that take interest income as the main source of income will face a significant decline in profitability (Pan \& Pan, 2014). This serves as the possible explanation for the negative relationship in our case, because despite of the wide range of money supply of $10.78 \%$ to $34.78 \%$, with a mean of $20.74 \%$, banks were not able to take advantage of that high supply of money. The results were not significant; that being the case, other factors could as well be working that triggers that relationship.

\section{Conclusions and Recommendations}

The TEA coefficient is negative to ROA and against expected sign, equity although it measures banks strength banks should not hold much proportion of equity. Banks should advance loans and invest in such project where risk is moderate and return is high. Due to high DIV ratio (30\%), Tanzanian banks have exhausted their diversification potential. A more diversification strategy would result into decrease in profitability. It would therefore be appropriate to reduce diversification to within $30 \%$. By increasing the size of the banking firms in Tanzania, it is possible to reduce cost as the banking sector is indicatively increasing in magnitude. The analysis shows that DAR have positive impact on profitability (ROA) and banks depending on deposits for funds can achieve better ROA.

Following the advice of Anathoglou (2006) the credit risk variable (PLT) is negatively related to bank profitability, banks should focus more on credit risk management; serious banking problems have arisen from the failure of banks to recognise impaired assets and create reserves for writing-off these assets. An immense help towards smoothing these anomalies would be provided by improving the transparency of the financial systems, which in turn will assist banks to evaluate credit risk more effectively and avoid problems associated with hazardous exposure. The lower bank risk and lower profitability coupled with a negative relationship for the BAR help to accounts for the fact that, Tanzanian banks are risk averse and therefore would not do much better if they would venture into more risky opportunities, and probably not large enough to absorb bigger risks for higher returns. 
Banks need to check on the managerial inefficiency that is contributing to bank losses. Following the advice of Obamuyi (2013) the findings implies that inefficient management of banks' expenses exist, increasing the cost of operations does not improves the performance of banks. The most important policy lesson to banks is that; reducing the cost of operations reduces the incidence of failure of the banks. As stated by Efficiency Structure (ES) hypothesis, an efficiently managed bank will earn higher profits than the less efficient ones. In a large study for Sub-Saharan Africa, in which Tanzania was included, Flamini et al. (2009) found that INF was positively related to ROA and NIM, arguing that banks were able to correctly forecast and anticipate inflation. But, our case (the Tanzania only case) proved the opposite, thus banks in Tanzania need to learn and improve on their forecasts and anticipation of inflation in order to avoid its surprises, and instead earn more profits from rising inflation.

\section{References}

Ahmad, S., Nafees, B., \& Khan, Z. A. (2012). Determinants of profitability of Pakistani banks: panel data evidence for the period 2001-2010. Journal of Business Studies Quarterly, 4(1), 149-165.

Alexiou, C., \& Sofoklis, V. (2009). Determinants of bank profitability: Evidence from the Greek banking sector. Economic Annals, 182, 93-118. http://dx.doi.org/10.2298/EKA0982093A

Almazari, A. A. (2014). Impact of internal factors on bank profitability: comparative study between Saudi Arabia and Jordan. Journal of Applied Finance \& Banking, 4(1), 1792-6580 (print version), 1792-6599 (online). London: Scienpress Ltd.

Ani, W. U., Ugwunta, D. O., Ezeudu, I. J., \& Ugwuanyi, G. O. (2012). An empirical assessment of the determinants of bank profitability in Nigeria: Bank characteristics panel evidence. Journal of Accounting and Taxation, 4(3), 38-43. http://dx.doi.org/10.5897/JAT11.034

Athanasoglou, P., Delis, M., \& Staikouras, C. (2006). Determinants of bank profitability in the south eastern European region. Social Science Electronic Publishing, pp. 1-17. MPRA Paper No. 10274. [Online] Available: http://mpra.ub.uni-muenchen.de/10274/

Baltagi, B. H. (2001). Econometric Analysis of Panel Data (2nd ed.). Chichester: John Wiley \& Sons.

Curak, M., Poposki, K., \& Pepur, S. (2012). Profitability Determinants of the Macedonian Banking Sector in Changign Environment. Procedia Social and Behavioral Sciences, 44, 406-416. http://dx.doi.org/10.1016/j.sbspro.2012.05.045

Davydenko, A. (2010). Determinants of Bank Profitability in Ukraine. Undergraduate Economic Review, 7(1) (2). [Online] Available: http://digitalcommons.iwu.edu/uer/vol7/iss1/2 
Elsiefy, E. (2013). Determinants of profitability of commercial banks in Qatar: Comparative overview between domestic conventional and Islamic banks during the period 2006-2011. International Journal of Economics and Management Sciences, 2(11), 108-142

Flamini, V., McDonald, C., \& Liliana, S. L. (2009). The Determinants of Commercial Bank Profitability in Sub-Saharan Africa. IMF Working Paper: African Department, WP/09/15, 1-30. http://dx.doi.org/10.5089/9781451871623.001

Gambacorta, L., Scatigna, M., \& Yang, J. (2014) Diversification and bank profitability: a nonlinear approach. Applied Economics Letters, 21(6), 438-441. http://dx.doi.org/10.1080/13504851.2013.866196

Gul, S., Irshad, F., \& Zaman, K. (2011). Fctors affecting bank profitability in Parkistan. The Romanian Economic Journal, 39, 61-87.

Hoffmann, P. S. (2011). Determinants of the profitability of the US banking industry. International Journal of Business and Social Science, 2(22) 255-269.

Jaber, J. J., \& Al-khawaldeh, A. A. (2014). The impact of internal and external factors on commercial banks profitability in Jordan. International Journal of Business and Management, 9(4), 22-30. http://dx.doi.org/10.5539/ijbm.v9n4p22

Kanwal, S., \& Nadeem, M. (2013). European Journal of Business and Social Sciences, 2(9), 186-201. [Online] Available: http://www.ejbss.com/recent.aspx

Moussa, M. M. (2012). Bank-specific and Macroeconomic Determinants of Bank Profitability: Case of Turkey. Dissertation (Msc. Banking and Finance)

Naceur, S. B. (2003). The determinants of the Tunisian banking industry profitability: panel evidence. Unpublished.

Obamuyi, T. M. (2013). Determinants of banks' profitability in a developing economy: Evidence from Nigeria. Organizations and Markets in Emerging Economies, 4(2), 97-111. [Online]

Available: http://www.om.ef.vu.lt/index.php?act=uploads.download\&file=\%2Fw3\%2Flt.vu.www4057 $\% 2$ Fwww $\% 2$ Fcms $\% 2$ Fuploads $\% 2$ Ffiles $\% 2$ FObamuyi.pdf\&code=de4d1 f684cef $213 \mathrm{dcf} 838 \mathrm{~b} 9$ db582199e

Ongore, V. O., \& Kusa, G. B. (2013). Determinants of Financial Performance of Commercial Banks in Kenya. International Journal of Economics and Financial Issues, 3(1), 237-252.

Pan, Q. H., \& Pan, M. L. (2014). The impact of macro-factors on the profitability of China's commercial banks in the decade after WTO accession. Open Journal of Social Sciences, 2, 64-69. http://dx.doi.org/10.4236/jss.2014.29011

Qin, X., \& Pastory, D. (2012) Commercial Banks Profitability Position: The Case of Tanzania. International Journal of Business and Management, 7(13) 136-144. http://dx.doi.org/10.5539/ijbm.v7n13p136 


\section{Macrothink}

Ramadan, I. Z., Kilani, Q. A., \& Kaddumi, T. A. (2011). Determinants of bank profitability: evidance from jordan. International Journal of Academic Research, 3(4), 160-191.

Saeed, M. S. (2014). Bank-related, industry-related and macroeconomic factors affecting bank profitability: a case of the United Kingdom. Research Journal of Finance and Accounting, 5(2), 42-50. [Online] Available: http://www.iiste.org/Journals/index.php/RJFA/article/download/10678/10883

Schipper, J. E. (2013). The Determinants of Bank Profitability through the Global Financial Crisis: Evidence from Slovakia and Poland, Dissertation, Haverford College Department of Economics. Unpublished.

Sufian, F., \& Noor, M. A. N. M. (2012). Determinants of bank Performance in a developing economy: does bank origins matters? Global Business Review, 13(1), 1-23. http://dx.doi.org/10.1177/097215091101300101

Wong, J., Fong, T., Wong, E., \& Choi, K. (2007). Determinants of the performance of banks in Hong Kong. Hong Kong Monetary Authority Quarterly Bulletin, 5-15. http://dx.doi.org/10.2139/ssrn.1032032

\section{Copyright Disclaimer}

Copyright for this article is retained by the author(s), with first publication rights granted to the journal.

This is an open-access article distributed under the terms and conditions of the Creative Commons Attribution license (http://creativecommons.org/licenses/by/3.0/). 